University of Nebraska - Lincoln

DigitalCommons@University of Nebraska - Lincoln

Agronomy \& Horticulture -- Faculty Publications

Agronomy and Horticulture Department

$9-1-2003$

\title{
Soybean Nitrogen Contribution to Corn and Sorghum in Western Corn Belt Rotations
}

Gary E. Varvel

University of Nebraska-Lincoln, gevarvel@windstream.net

Wallace Wilhelm

University of Nebraska-Lincoln, wwilhelm1@unl.edu

Follow this and additional works at: https://digitalcommons.unl.edu/agronomyfacpub

Part of the Plant Sciences Commons

Varvel, Gary E. and Wilhelm, Wallace, "Soybean Nitrogen Contribution to Corn and Sorghum in Western Corn Belt Rotations" (2003). Agronomy \& Horticulture -- Faculty Publications. 5.

https://digitalcommons.unl.edu/agronomyfacpub/5

This Article is brought to you for free and open access by the Agronomy and Horticulture Department at DigitalCommons@University of Nebraska - Lincoln. It has been accepted for inclusion in Agronomy \& Horticulture -Faculty Publications by an authorized administrator of DigitalCommons@University of Nebraska - Lincoln. 


\title{
Soybean Nitrogen Contribution to Corn and Sorghum in Western Corn Belt Rotations
}

\author{
G. E. Varvel* and W. W. Wilhelm
}

\begin{abstract}
Increased $\mathbf{N}$ availability is often associated with the beneficial effects of rotating grain and legume crops. Our objective was to utilize yield response data from two long-term studies to determine the amount of $\mathrm{N}$ supplied by soybean [Glycine $\max$ (L.) Merr.] for subsequent nonlegume crops in 2-yr rotations. The experiments were located in eastern Nebraska (Mead) (rainfed) and central Nebraska (Shelton) (irrigated). Continuous corn (Zea mays L.) and soybeancorn cropping systems were present in both experiments while continuous sorghum [Sorghum bicolor (L.) Moench] and soybean-sorghum cropping systems were present at Mead only. Three $\mathbf{N}$ fertilizer rates were used for the study at Mead and five at Shelton. Nitrogen fertilizer replacement values were estimated using graphical and regression techniques. Results from both techniques indicated that corn in the rainfed experiment at Mead (20 yr) and irrigated experiment at Shelton (10 yr) obtained approximately $65 \mathrm{~kg} \mathrm{~N} \mathrm{ha}^{-1} \mathrm{yr}^{-1}$ from soybean in a 2-yr rotation with soybean at both locations. Sorghum in the rainfed experiment at Mead (20 yr) obtained approximately $80 \mathrm{~kg}$ $\mathrm{N} \mathrm{ha}^{-1} \mathrm{yr}^{-1}$ from soybean in a soybean-sorghum rotation. Current fertilizer $\mathbf{N}$ applications based on fall or early-spring soil tests used extensively in this area need to be reduced by these amounts for corn and sorghum grown in 2-yr rotations with soybean when grown on medium- to fine-textured soils in the western Corn Belt to reduce excess $\mathbf{N}$ available for loss and to reduce unnecessary input costs.
\end{abstract}

S IENTISTS AND FARMERS have recognized for centuries the beneficial effects of crop rotations. However, there is no consensus on the specific causes. Historically, cropping systems with various crop species grown in sequences of differing lengths were widely used because crops were shown to produce more biomass and grain when grown in rotation. In more recent times, usage of crop rotation in production systems has ebbed and flowed in the USA as farm programs and technology changed. The substantial increase in availability of synthetic fertilizers and pesticides during the 1950s and early 1960s induced many farmers to switch to monoculture production systems, which they felt could forever replace crop rotation without loss in yield (Bullock, 1992). Since that time, opinions have changed, and crop rotation has again become a desirable strategy in crop production systems. Bullock (1992) cited many examples of different types of crop rotation systems used both in the USA and around the world and their beneficial effects on crop yields. He also noted that many of the factors and mechanisms responsible for the so-called rotation effect are not completely understood. Nitrogen availability is usually identified as responsible for the

USDA-ARS and Dep. of Agron., Univ. of Nebraska, Lincoln, NE 68583. Joint contribution of USDA-ARS and the Nebraska Agric. Res. Div., Journal Ser. no. 13821. Received 30 Aug. 2002. *Corresponding author (gvarvel1@unl.edu).

Published in Agron. J. 95:1220-1225 (2003).

(c) American Society of Agronomy

677 S. Segoe Rd., Madison, WI 53711 USA greatest proportion of the beneficial effects of crop rotation, but other factors, including reduced weed, disease, and insect problems, can also be important.

Corn is now commonly grown in a 2-yr rotation with soybean or other similar short-term (2- to 3-yr) rotations. As a result, any beneficial effect for growing corn in rotation with a legume is highly relevant in today's cropping systems. Some researchers (Baldock and Musgrave, 1979; Baldock et al., 1981) have suggested that the $\mathrm{N}$ contribution from the legume is responsible for most of this beneficial rotation effect to corn, but other researchers (Russelle et al., 1987; Hesterman et al., 1987) feel this contribution is overestimated.

Several approaches have been used to determine the $\mathrm{N}$ contribution from the legume in rotations, and the different techniques used to estimate the $\mathrm{N}$ contribution to the successive crop could be part of the discrepancy. LaRue and Patterson (1981) discussed many of these methods in detail and stated that the fertilizer replacement value (FRV) and ${ }^{15} \mathrm{~N}$ methods to estimate the $\mathrm{N}$ contribution to the following crop were among the most commonly used. Bullock (1992) indicates that FRV methodology has probably overestimated the amount of $\mathrm{N}$ supplied by the legume. In addition, Ladd (1981) and Harris and Hesterman (1990) using ${ }^{15} \mathrm{~N}$ methodology found that only 15 to $25 \%$ of $\mathrm{N}$ from the previous legume cover crops was recovered by the following nonlegume crop.

Using the FRV method, results have varied from those similar to Ding et al. (1998) where they found that soybean supplied $30 \mathrm{~kg} \mathrm{~N}^{-1}$ to a following corn crop in Ontario while Bundy et al. (1993) found no consistent amount of $\mathrm{N}$ supplied to the following corn crop by soybean in Wisconsin. Other problems with the FRV method include species differences regarding the amount of $\mathrm{N}$ supplied to subsequent nonlegume crops. Blevins et al. (1990) reported that legumes provided 65 to $75 \mathrm{~kg} \mathrm{~N} \mathrm{ha}^{-1}$ to corn and 125 to $135 \mathrm{~kg} \mathrm{~N}^{-1}$ to sorghum using the FRV method. In contrast to the FRV method, the ${ }^{15} \mathrm{~N}$ method is far more resource intensive. Specialized and costly fertilizer $\left({ }^{15} \mathrm{~N}\right.$-tagged) and analytical tools (mass spectrometer) must be used to obtain data required to calculate $\mathrm{N}$ contributions from legumes using ${ }^{15} \mathrm{~N}$ tracers. This being the case, very few data are available using ${ }^{15} \mathrm{~N}$ to construct a general consensus on the legume $\mathrm{N}$ contribution, especially from long-term experiments conducted for many years covering varying environmental conditions. On the other hand, FRV can be computed with relatively easy-to-gather data (yield of a nonlegume crop over a series of $\mathrm{N}$ fertilizer rates in both monoculture and rotation with a legume). These data are frequently collected in cropping system experiments. Therefore, estimates using the FRV can be made

Abbreviations: FRV, fertilizer replacement value. 
over a wide range of environmental conditions and management practices to arrive at a consensus estimate for the $\mathrm{N}$ contribution by the legume to the nonlegume in a rotation system.

Although the preceding discussion indicates that problems exist with each method of estimating the amount of $\mathrm{N}$ supplied by a legume, it is critical that some reasonable estimate of the $\mathrm{N}$ contribution be made. Applications of $\mathrm{N}$ fertilizer at rates in excess of those needed for optimum yield results in inefficient use of resources and can result in excess $\mathrm{N}$ in the soil, increasing the amount of $\mathrm{N}$ available for environmental degradation through leaching or denitrification. Our objective was to utilize yield response data from two long-term studies to determine the amount of $\mathrm{N}$ supplied by soybean to a following corn or sorghum crop in 2-yr rotations.

\section{MATERIALS AND METHODS}

Results from two experiments were used for these analyses. The first experiment was located on the Agronomy Farm at the University of Nebraska Agricultural Research and Development Center near Mead, NE, on a well-drained Sharpsburg silty clay loam (fine, smectitic, mesic Typic Argiudoll). This site has an average organic matter content of $31 \mathrm{~g} \mathrm{~kg}^{-1}$ and soil test $\mathrm{P}$ and $\mathrm{K}$ levels in the very high categories in the surface $75 \mathrm{~mm}$ (according to University of Nebraska Soil Testing Laboratory fact sheets). The experiment is rainfed.

Seven cropping systems (three monoculture and two 2-yr and two 4-yr rotations) with three rates of $\mathrm{N}$ fertilizer were included in the study. In this analysis, only results from the continuous corn, continuous sorghum, and the 2-yr cornsoybean and sorghum-soybean cropping systems are included. Each phase of the corn-soybean and sorghum-soybean rotation occurs every year. Treatments were assigned to experimental units ( 9 by $32 \mathrm{~m}$ ) in factorial combinations of rotation and crop within rotation in five randomized complete blocks in 1982. No fertilizer $\mathrm{N}$ was applied to any of the monoculture or rotation plots that cropping season.

Three subplots $(9$ by $10 \mathrm{~m}$ ) separated by $1-\mathrm{m}$ alleys were randomly assigned a 0 , low, or high $\mathrm{N}$ rate within each wholeplot treatment starting with the 1983 cropping season. Nitrogen rates were 0,90 , or $180 \mathrm{~kg} \mathrm{~N} \mathrm{ha}^{-1}$ for corn and sorghum and 0,34 , or $68 \mathrm{~kg} \mathrm{~N} \mathrm{ha}^{-1}$ for soybean. Nitrogen was sidedressed as liquid urea ammonium nitrate solution (28-0-0) in 1983 and 1984, and broadcast as granular ammonium nitrate (34-0-0) in subsequent years. Nitrogen applications were made in late May or early to mid-June for all three crops.

Cultural practices were similar to those used by local farmers. Previous crop residue on corn and sorghum plots was shredded in mid- to late November each year. All plots were tilled once or twice with a tandem disk just before planting each year for all crops. Crop varieties and hybrids were evaluated and changed if necessary every $4 \mathrm{yr}$ at completion of each full cycle of the longest rotations (4-yr rotation, which is not considered in this paper). Corn was seeded in 76-cm rows at approximately 47000 seed $\mathrm{ha}^{-1}$ in early May as soil conditions permitted. Weed control was accomplished using combinations of broad-spectrum herbicides in preemergence and postemergence applications, cultivation, and hand weeding. Herbicides were selected for each rotation to obtain optimum weed control and to reduce carryover problems for successive crops in that rotation. Soybean and grain sorghum were seeded in 76-cm rows at rates of approximately 370000 and 173000 seeds ha $^{-1}$, respectively. Both crops were planted in mid- to late May or early June according to conditions each year. Weed control and herbicide selection for each crop were accomplished using the same criteria described above for corn. Corn and sorghum were harvested with a plot combine after reaching physiological maturity for grain yield in each year, generally in early to mid-October. Yield data were adjusted to $155 \mathrm{~g}^{-1} \mathrm{~kg}^{-1}$ for corn and $140 \mathrm{~g}^{-1} \mathrm{~kg}^{-1}$ for sorghum. Additional background and management information were presented in Peterson and Varvel (1989a, 1989b, 1989c).

The second experiment was an irrigated monoculture corn and soybean-corn cropping systems study located in the Platte Valley near Shelton, NE, on a Hord silt loam (fine-silty, mixed, mesic, Pachic Haplustoll). A split-split-split plot design with four replications was used, with cropping systems as main plots, corn hybrids as subplots, and $\mathrm{N}$ fertilizer regimes as sub-subplots. All phases of the monoculture corn and soybean-corn systems were present each year. Four commercially available Pioneer brand corn hybrids differing in yield potential and maturity were used in both monoculture and rotation systems. Four hybrids $(3162,3379,3394$, and 3417) were used from 1993-2000, and then a switch was made to four new hybrids with similar growth characteristics (32R42, 33B50, 33G26, and 33P66) for 2001 and beyond. All corn hybrids were planted between late April and mid-May in eight-row (91-cm row spacing) by 15.2-m-long plots at approximately 74000 seeds $\mathrm{ha}^{-1}$. Soybean in the soybean-corn rotation was planted in early to mid-May using production practices typical to the area. Irrigation was provided as needed with a linear drive sprinkler system.

Nitrogen fertilizer, as ammonium nitrate, was broadcast on the soil surface for both crops in late May or early June. Fertilizer $\mathrm{N}$ regimes included $\mathrm{N}$ fertilizer rates of $0,50,100$, 150 , and $200 \mathrm{~kg} \mathrm{~N} \mathrm{ha}^{-1}$ for the 1993-2001 growing seasons.

Final corn grain yield was determined with a plot combine by harvesting three of the center rows for the entire length of each plot. Yield data were adjusted to $155 \mathrm{~g} \mathrm{~kg}^{-1}$ moisture.

Data for the paper were analyzed both within and across years. All statistical analyses were performed using the Statistical Analyses System (SAS Inst., 1992).

\section{RESULTS AND DISCUSSION}

Corn grain yields in the monoculture corn and soybean-corn cropping systems at the rainfed Mead location ranged from 1.02 to $12.05 \mathrm{Mg} \mathrm{ha}^{-1}$ during the $20 \mathrm{yr}$ of study (Tables 1 and 2). There was a significant response to $\mathrm{N}$ fertilizer in all but one of the years in the continuous corn (Table 1) and in 16 of the $20 \mathrm{yr}$ in the soybean-corn (Table 2) cropping systems. During the same period, sorghum grain yields ranged from 0.72 to $10.20 \mathrm{Mg} \mathrm{ha}^{-1}$ in the monoculture sorghum and soybean-sorghum systems (Tables 3 and 4). Significant grain yield responses to $\mathrm{N}$ fertilizer were obtained in 18 of $20 \mathrm{yr}$ in continuous sorghum (Table 3 ) but only in 8 of $20 \mathrm{yr}$ in the soybeansorghum cropping system (Table 4). Significant responses to $\mathrm{N}$ fertilizer were obtained in both cropping systems for both corn and sorghum when analyzed over the $20 \mathrm{yr}$ of the study (Tables $1-4$ ).

Corn grain yields at the irrigated site at Shelton, NE, ranged from 3.51 to $14.33 \mathrm{Mg} \mathrm{ha}^{-1}$ during the $10 \mathrm{yr}$ of the study (Tables 5 and 6 ). Results were similar to those obtained at the Mead site, with a significant response to $\mathrm{N}$ fertilizer in all $10 \mathrm{yr}$ in continuous corn (Table 5) and in 8 of the $10 \mathrm{yr}$ in soybean-corn (Table 6) cropping 
Table 1. Continuous corn grain yields as affected by $\mathbf{N}$ fertilizer rate from 1983 through 2002 at Mead, NE (rainfed).

\begin{tabular}{|c|c|c|c|c|}
\hline \multirow[b]{3}{*}{ Year } & \multicolumn{4}{|c|}{ Grain yield } \\
\hline & \multicolumn{3}{|c|}{$\mathrm{N}$ fertilizer rate $\left(\mathrm{kg} \mathrm{ha}^{-1}\right)$} & \multirow{2}{*}{$\begin{array}{c}\mathrm{N} \text { rate } \\
\text { significance }\end{array}$} \\
\hline & $\mathbf{0}$ & 90 & 180 & \\
\hline & & Mg ha & - & \\
\hline 1983 & 3.19 & 4.43 & 4.13 & $*$ \\
\hline 1984 & 3.38 & 4.72 & 5.05 & $\mathbf{N S} \dagger$ \\
\hline 1985 & 6.25 & 9.19 & 10.27 & $* * *$ \\
\hline 1986 & 4.87 & 9.00 & 11.98 & **** \\
\hline 1987 & 4.35 & 7.77 & 7.73 & $* *$ \\
\hline 1988 & 3.83 & 5.64 & 6.99 & $* *$ \\
\hline 1989 & 3.62 & $\mathbf{7 . 8 3}$ & 7.88 & $* * *$ \\
\hline 1990 & 4.45 & 6.98 & 7.23 & $* * *$ \\
\hline 1991 & 4.17 & 7.77 & 7.47 & $*$ \\
\hline 1992 & 5.12 & 9.93 & 11.11 & $* * *$ \\
\hline 1993 & 3.74 & 7.55 & 8.93 & $* * *$ \\
\hline 1994 & 4.15 & 8.13 & 10.57 & $* * *$ \\
\hline 1995 & 1.02 & 1.98 & 3.84 & $* * *$ \\
\hline 1996 & 5.60 & 8.76 & 9.25 & $* * *$ \\
\hline 1997 & 2.36 & 8.71 & 8.68 & $* * *$ \\
\hline 1998 & 2.63 & 8.07 & 9.50 & $* * *$ \\
\hline 1999 & 3.87 & 9.33 & 10.08 & $* * *$ \\
\hline 2000 & 3.44 & 6.92 & 7.20 & $* * *$ \\
\hline 2001 & 4.06 & 7.00 & 7.57 & $*$ \\
\hline 2002 & 2.82 & 6.96 & 6.46 & $* * *$ \\
\hline 1983-2002 & 3.85 & 7.33 & 8.10 & $* * *$ \\
\hline
\end{tabular}

* Significant at the 0.05 probability level. ** Significant at the 0.01 probability level. *** Significant at the 0.001 probability level.

$\uparrow$ NS, nonsignificant.

systems. Similarly, significant responses to $\mathrm{N}$ fertilizer were obtained in both cropping systems when analyzed over the $10 \mathrm{yr}$ of the study (Tables 5 and 6). As expected, average corn grain yields over the duration of the study were much greater at the irrigated $\left(10.37 \mathrm{Mg} \mathrm{ha}^{-1}\right)$ than the rainfed $\left(7.16 \mathrm{Mg} \mathrm{ha}^{-1}\right)$ location.

Table 2. Corn grain yields from soybean-corn rotations as affected by $\mathbf{N}$ fertilizer rate from 1983 through 2002 at Mead, NE (rainfed).

\begin{tabular}{|c|c|c|c|c|}
\hline \multirow[b]{3}{*}{ Year } & \multicolumn{4}{|c|}{ Grain yield } \\
\hline & \multicolumn{3}{|c|}{$\mathbf{N}$ fertilizer $\left(\mathrm{kg} \mathrm{ha}^{-1}\right)$} & \multirow{2}{*}{$\begin{array}{c}\mathbf{N} \text { rate } \\
\text { significance }\end{array}$} \\
\hline & $\mathbf{0}$ & 90 & 180 & \\
\hline & - & Mg ha & - & \\
\hline 1983 & 4.78 & 5.43 & 4.84 & $\mathbf{N S} \dagger$ \\
\hline 1984 & 5.90 & 7.54 & 6.18 & $*$ \\
\hline 1985 & 7.04 & 11.07 & 10.40 & $* * *$ \\
\hline 1986 & 9.38 & 11.23 & 11.75 & $* *$ \\
\hline 1987 & 8.25 & 11.42 & 10.41 & $*$ \\
\hline 1988 & 6.73 & 7.63 & 6.61 & NS \\
\hline 1989 & 4.91 & 4.13 & 6.06 & NS \\
\hline 1990 & 5.13 & 6.59 & 7.86 & $* * *$ \\
\hline 1991 & 6.87 & 9.24 & 8.65 & $*$ \\
\hline 1992 & 7.82 & 12.01 & 12.05 & $* *$ \\
\hline 1993 & 7.33 & 9.54 & 8.95 & $*$ \\
\hline 1994 & 8.32 & 10.98 & 11.11 & $* * *$ \\
\hline 1995 & 3.36 & 4.34 & 4.21 & $* *$ \\
\hline 1996 & 8.18 & 9.52 & 8.89 & + \\
\hline 1997 & 5.89 & 8.24 & 8.79 & $* *$ \\
\hline 1998 & 7.15 & 10.39 & 9.66 & $* *$ \\
\hline 1999 & 7.53 & 10.73 & 11.31 & $* * *$ \\
\hline 2000 & 7.32 & 8.99 & 8.44 & NS \\
\hline 2001 & 5.50 & 7.09 & 7.43 & $* *$ \\
\hline 2002 & 3.97 & 5.65 & 6.27 & $* *$ \\
\hline 1983-2002 & 6.57 & 8.59 & 8.49 & $* * *$ \\
\hline
\end{tabular}

* Significant at the 0.05 probability level. ** Significant at the 0.01 probability level. **** Significant at the 0.001 probability level.

$\dagger$ NS, nonsignificant.

$\$$ Significant at the 0.10 probability level.
Table 3. Continuous sorghum grain yields as affected by $\mathbf{N}$ fertilizer rate from 1983 through 2002 at Mead, NE (rainfed).

\begin{tabular}{|c|c|c|c|c|}
\hline \multirow[b]{3}{*}{ Year } & \multicolumn{4}{|c|}{ Grain yield } \\
\hline & \multicolumn{3}{|c|}{$\mathbf{N}$ fertilizer $\left(\mathrm{kg} \mathrm{ha}^{-1}\right)$} & \multirow{2}{*}{$\begin{array}{c}\text { N rate } \\
\text { significance }\end{array}$} \\
\hline & $\mathbf{0}$ & 90 & 180 & \\
\hline & \multicolumn{3}{|c|}{$\longrightarrow \mathrm{Mg} \mathrm{ha}^{-1} \longrightarrow$} & \\
\hline 1983 & 2.87 & 4.04 & 4.52 & $\dagger$ \\
\hline 1984 & 3.17 & 5.97 & 5.58 & $* *$ \\
\hline 1985 & 5.30 & 8.66 & 8.27 & **** \\
\hline 1986 & 5.23 & 8.25 & 8.93 & $* * *$ \\
\hline 1987 & 4.01 & 5.55 & 5.77 & NS \\
\hline 1988 & 5.62 & 7.44 & 7.46 & $\dagger$ \\
\hline 1989 & 1.79 & 6.10 & $\mathbf{7 . 5 4}$ & $* * *$ \\
\hline 1990 & 4.92 & 8.15 & 8.41 & $* * *$ \\
\hline 1991 & 3.06 & 8.61 & 10.20 & $* * *$ \\
\hline 1992 & 2.58 & 5.39 & 6.18 & $* * *$ \\
\hline 1993 & 1.08 & 3.04 & 3.72 & $* * *$ \\
\hline 1994 & 2.80 & 5.84 & 5.87 & $* *$ \\
\hline 1995 & 0.72 & 1.38 & 3.69 & $* * *$ \\
\hline 1996 & 5.06 & 7.20 & 7.48 & $*$ \\
\hline 1997 & 6.58 & 7.69 & 7.94 & NS \\
\hline 1998 & 4.91 & 7.56 & 7.59 & $* *$ \\
\hline 1999 & 3.68 & 5.92 & 7.08 & ** \\
\hline 2000 & 4.00 & 7.37 & 7.89 & ** \\
\hline 2001 & 1.97 & 4.33 & 5.25 & $* * *$ \\
\hline 2002 & 3.79 & 5.60 & 5.57 & $* *$ \\
\hline 1983-2002 & 3.66 & 6.21 & 6.75 & $* * *$ \\
\hline
\end{tabular}

* Significant at the 0.05 probability level. ** Significant at the 0.01 probability level. *** Significant at the $\mathbf{0 . 0 0 1}$ probability level. $\dagger$ Significant at the $\mathbf{0 . 1 0}$ probability level. † NS, nonsignificant.

Grain yield responses (averaged over the $20 \mathrm{yr}$ of the study) to $\mathrm{N}$ fertilizer applications for both crops and cropping systems (continuous corn and soybean-corn; continuous sorghum and soybean-sorghum) at the Mead location are shown in Fig. 1 and 2. Similarly, grain yield responses (averaged over the $10 \mathrm{yr}$ of the study)

Table 4. Sorghum grain yields from soybean-sorghum rotations as affected by $\mathrm{N}$ fertilizer rate from 1983 thorugh 2002 at Mead, NE (rainfed).

\begin{tabular}{|c|c|c|c|c|}
\hline \multirow[b]{3}{*}{ Year } & \multicolumn{4}{|c|}{ Grain yield } \\
\hline & \multicolumn{3}{|c|}{$\mathrm{N}$ fertilizer rate $\left(\mathrm{kg} \mathrm{ha}^{-1}\right)$} & \multirow{2}{*}{$\begin{array}{c}\mathbf{N} \text { rate } \\
\text { significance }\end{array}$} \\
\hline & $\mathbf{0}$ & 90 & 180 & \\
\hline & & $\operatorname{Ig} \mathbf{h a}^{-}$ & - & \\
\hline 1983 & 5.56 & 5.08 & 4.74 & $\mathbf{N S} \dagger$ \\
\hline 1984 & 4.17 & 5.11 & 5.85 & $\dagger$ \\
\hline 1985 & $\mathbf{7 . 0 3}$ & 7.94 & 7.78 & NS \\
\hline 1986 & $\mathbf{7 . 8 0}$ & 8.83 & 8.45 & $* *$ \\
\hline 1987 & 5.83 & 6.98 & 5.40 & + \\
\hline 1988 & 6.96 & 7.26 & 7.86 & NS \\
\hline 1989 & 5.67 & 6.70 & 6.77 & NS \\
\hline 1990 & 7.08 & 7.87 & 8.05 & NS \\
\hline 1991 & 7.35 & 9.01 & 8.77 & $*$ \\
\hline 1992 & 5.54 & 6.56 & 6.39 & $\ddagger$ \\
\hline 1993 & 4.27 & 4.86 & 5.28 & $*$ \\
\hline 1994 & 5.90 & 6.08 & 7.22 & NS \\
\hline 1995 & 2.04 & 2.68 & 4.10 & $*$ \\
\hline 1996 & 7.77 & 6.32 & 8.00 & NS \\
\hline 1997 & 8.06 & 8.52 & 8.87 & NS \\
\hline 1998 & 7.74 & 7.19 & 8.14 & NS \\
\hline 1999 & 5.51 & 6.33 & 6.77 & $*$ \\
\hline 2000 & 7.44 & 7.95 & 8.63 & NS \\
\hline 2001 & 4.10 & 3.56 & 4.05 & NS \\
\hline 2002 & 5.72 & 6.16 & 6.71 & NS \\
\hline 1983-2002 & 6.08 & 6.55 & 6.89 & $* * *$ \\
\hline
\end{tabular}

* Significant at the 0.05 probability level. ** Significant at the 0.01 probability level. **** Significant at the 0.001 probability level. $\dagger$ NS, nonsignificant.

$¥$ Significant at the 0.10 probability level. 
Table 5. Continuous corn grain yields as affected by $\mathbf{N}$ fertilizer rate from 1993 through 2002 at Shelton, NE (irrigated).

\begin{tabular}{|c|c|c|c|c|c|c|}
\hline \multirow[b]{3}{*}{ Year } & \multicolumn{6}{|c|}{ Grain yield } \\
\hline & \multicolumn{5}{|c|}{$\mathrm{N}$ fertilizer rate $\left(\mathrm{kg} \mathrm{ha}^{-1}\right)$} & \multirow{2}{*}{$\begin{array}{c}\mathrm{N} \text { rate } \\
\text { significance }\end{array}$} \\
\hline & $\mathbf{0}$ & 50 & 100 & 150 & 200 & \\
\hline & \multicolumn{5}{|c|}{ Mg ha ${ }^{-1}$} & \\
\hline 1993 & 3.97 & 5.80 & 7.66 & 8.05 & 8.75 & $* * *$ \\
\hline 1994 & 7.15 & 7.92 & 8.16 & 7.90 & 8.03 & $* *$ \\
\hline 1995 & 8.62 & 10.33 & 10.46 & 10.59 & 10.47 & $* * *$ \\
\hline 1996 & 8.77 & 11.04 & 12.29 & 12.67 & 12.82 & $* * *$ \\
\hline 1997 & 10.97 & 12.35 & 13.00 & 13.40 & 13.32 & $* * *$ \\
\hline 1998 & 6.61 & 9.20 & 11.19 & 11.84 & 11.95 & $* * *$ \\
\hline 1999 & 7.85 & 10.13 & 11.30 & 11.59 & 11.96 & $* * *$ \\
\hline 2000 & 4.73 & 9.15 & 11.74 & 12.07 & 11.93 & $* * *$ \\
\hline 2001 & 3.51 & 6.94 & 9.16 & 10.41 & 10.70 & $* * *$ \\
\hline 2002 & 4.93 & 8.11 & 10.20 & 11.06 & 11.54 & $* * *$ \\
\hline 1993-2002 & 6.71 & 9.10 & 10.52 & 10.96 & 11.15 & $* * *$ \\
\hline
\end{tabular}

** Significant at the 0.01 probability level.

*** Significant at the 0.001 probability level.

to $\mathrm{N}$ fertilizer applications for continuous corn and soybean-corn at the Shelton location are shown in Fig. 3.

Nitrogen FRVs for soybean at both locations were estimated graphically from plots of the grain yield response to $\mathrm{N}$ fertilizer (Fig. 1-3). First, we found the grain yield in the monoculture systems equal to that in the soybean-corn and soybean-sorghum systems without any $\mathrm{N}$ fertilizer applied. The amount of $\mathrm{N}$ fertilizer required to obtain that yield was determined, which is the N FRV. Using this method, N FRVs of approximately $65 \mathrm{~kg} \mathrm{ha}^{-1}$ at Mead (Fig. 1) and $72 \mathrm{~kg} \mathrm{ha}^{-1}$ at Shelton (Fig. 3) for the following corn crop were obtained. For sorghum in the soybean-sorghum cropping system at Mead, a fertilizer $\mathrm{N}$ replacement value of approximately $83 \mathrm{~kg} \mathrm{ha}^{-1}$ was obtained (Fig. 2).

To confirm these approximations, regression analyses were applied to the data from both locations to derive equations for the $\mathrm{N}$ response. Continuous corn and sorghum grain yield data from Mead were best described
Table 6. Corn grain yields from soybean-corn rotations as affected by $\mathbf{N}$ fertilizer rate from 1993 through 2002 at Shelton, NE (irrigated).

\begin{tabular}{|c|c|c|c|c|c|c|}
\hline \multirow[b]{3}{*}{ Year } & \multicolumn{6}{|c|}{ Grain yield } \\
\hline & \multicolumn{5}{|c|}{$\mathrm{N}$ fertilizer rate $\left(\mathrm{kg} \mathrm{ha}^{-1}\right)$} & \multirow{2}{*}{$\begin{array}{c}\mathrm{N} \text { rate } \\
\text { significance }\end{array}$} \\
\hline & $\mathbf{0}$ & 50 & 100 & 150 & 200 & \\
\hline & \multicolumn{5}{|c|}{ - Mg ha $\mathbf{h}^{-1}$} & \\
\hline 1993 & 7.04 & 7.56 & 7.67 & 7.50 & 7.46 & $\mathbf{N S} \dagger$ \\
\hline 1994 & 8.54 & 8.47 & 8.47 & 8.82 & 8.85 & NS \\
\hline 1995 & 10.54 & 11.39 & 11.64 & 11.50 & 11.40 & $* * *$ \\
\hline 1996 & 11.45 & 12.58 & 13.00 & 12.67 & 12.79 & $* * *$ \\
\hline 1997 & 13.63 & 14.33 & 14.15 & 14.07 & 13.88 & $\doteqdot$ \\
\hline 1998 & 9.70 & 11.57 & 12.55 & 12.42 & 12.63 & $* * *$ \\
\hline 1999 & 9.68 & 11.48 & 11.90 & 11.87 & 12.01 & $* * *$ \\
\hline 2000 & 9.50 & 11.62 & 12.43 & 12.27 & 12.25 & $* * *$ \\
\hline 2001 & 8.79 & 10.61 & 11.82 & 11.91 & 11.66 & $* * *$ \\
\hline 2002 & 8.60 & 10.50 & 11.68 & 11.81 & 11.69 & $* * *$ \\
\hline 1993-2002 & 9.75 & 11.01 & 11.53 & 11.49 & 11.46 & $* * *$ \\
\hline
\end{tabular}

**** Significant at the 0.001 probability level.

$\dagger$ NS, nonsignificant.

$\$$ Significant at the 0.10 probability level.

by a quadratic response curve, shown below in Eq. [1] and [2] for Mead corn and sorghum, respectively. Similarly, Eq. [3] describes the best-fit function for the continuous corn grain yield data from Shelton. Using these equations, corn and sorghum grain yields following soybean without any $\mathrm{N}$ fertilizer $\left(0 \mathrm{~kg} \mathrm{~N}\right.$ ha ${ }^{-1}$ fertilizer rate) applied were substituted for grain yield in each of the appropriate response equations, and the equation was solved to determine $\mathrm{N}$, the fertilizer $\mathrm{N}$ replacement value. Using this approach, FRVs of $62.8 \mathrm{~kg} \mathrm{ha}^{-1}$ at Mead and $67.7 \mathrm{~kg} \mathrm{ha}^{-1}$ at Shelton for the following corn crop were obtained. In the soybean-sorghum system at Mead, a FRV of $82.9 \mathrm{~kg} \mathrm{ha}^{-1}$ was obtained. These values agree closely with those obtained using the graphical technique described above.

$$
\begin{aligned}
\text { Grain yield }= & 3.85+0.054 \times(\mathrm{N} \text { rate }) \\
& -0.00017 \times(\mathrm{N} \text { rate })^{2} \quad r^{2}=0.92
\end{aligned}
$$

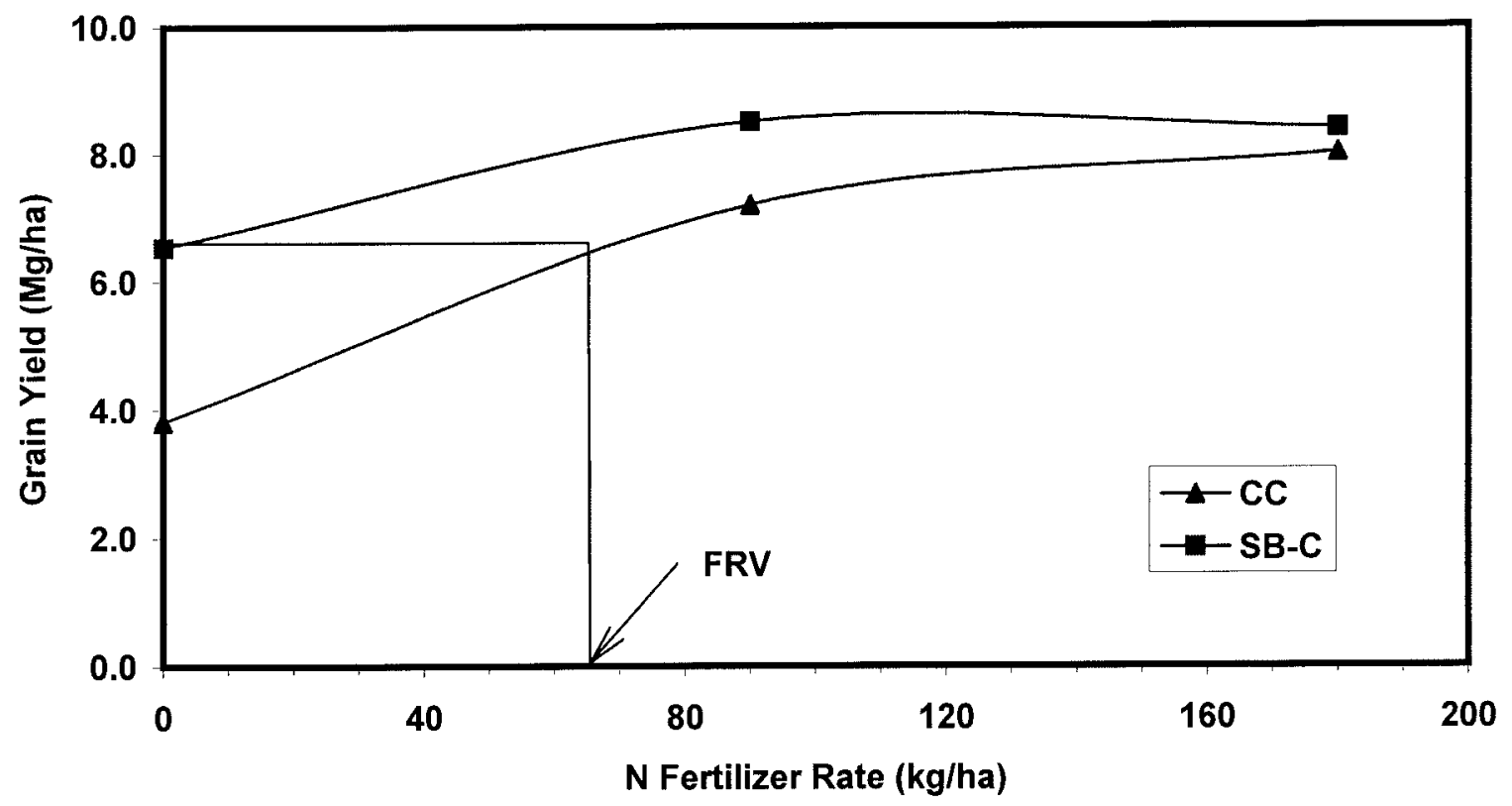

Fig. 1. Average corn grain yield response to $\mathbf{N}$ fertilizer applications in continuous corn (CC) and soybean-corn (SB-C) rainfed cropping systems at Mead, NE (1983-2002). FRV, fertilizer replacement value. 


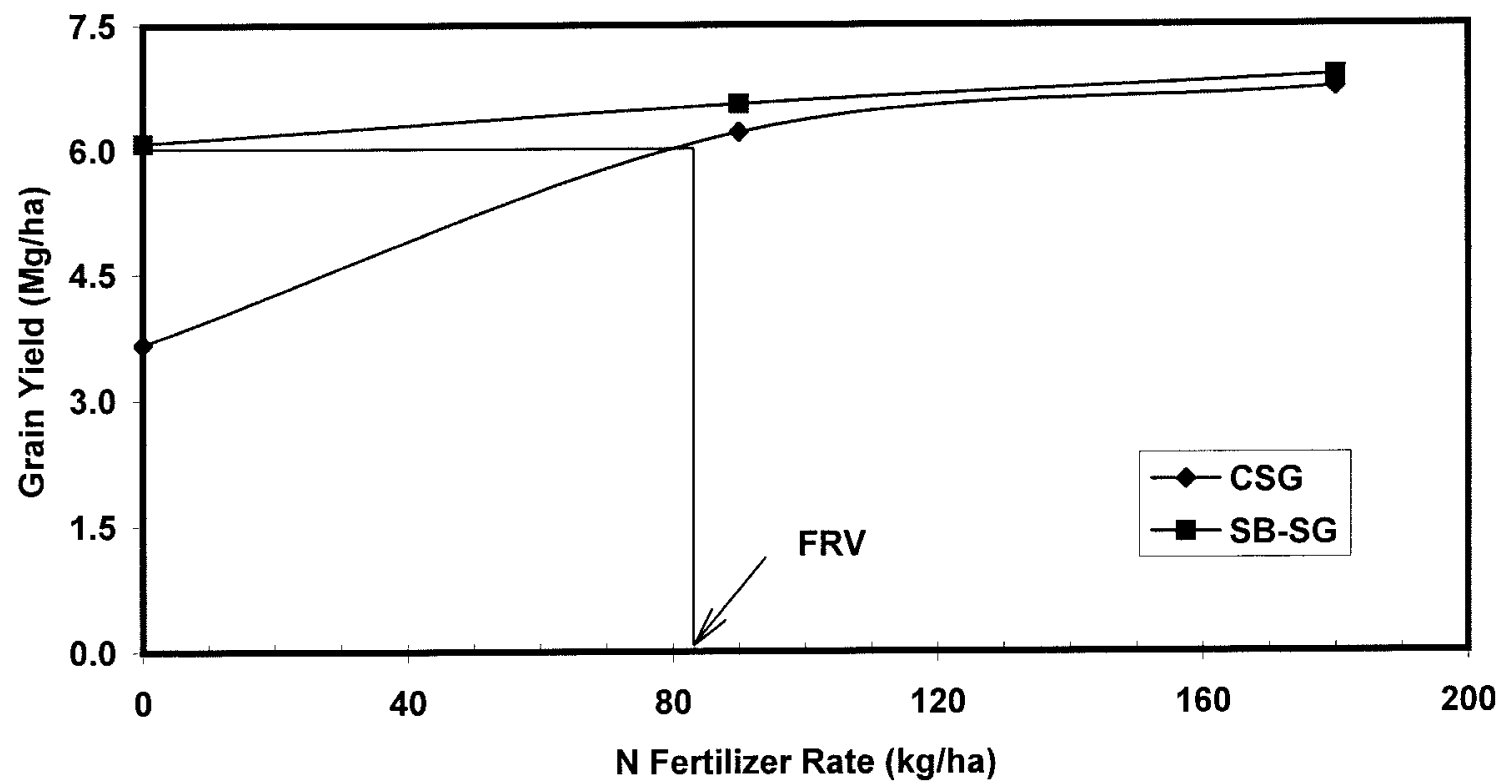

Fig. 2. Average sorghum grain yield response to $\mathrm{N}$ fertilizer applications in continuous sorghum (CSG) and soybean-sorghum (SB-SG) rainfed cropping systems at Mead, NE (1983-2002). FRV, fertilizer replacement value.

Grain yield $=3.66+0.039 \times(\mathrm{N}$ rate $)$

$$
-0.000124 \times(\mathrm{N} \text { rate })^{2} \quad r^{2}=0.90
$$

Grain yield $=6.71+0.053 \times(\mathrm{N}$ rate $)$

$$
-0.00005 \times(\mathrm{N} \text { rate })^{2}
$$

$$
\begin{aligned}
-0.0000015 & \times(\mathrm{N} \text { rate })^{3}+0.00000000493 \\
& \times(\mathrm{N} \text { rate })^{4} \quad r^{2}=0.95
\end{aligned}
$$

In either case, fertilizer $\mathrm{N}$ replacement values estimated by the graphical technique or calculated using regression analyses are greater than amounts usually credited by scientists and consultants when making fertilizer $\mathrm{N}$ recommendations for corn following soybean in the western Corn Belt. Bullock (1992) noted in his discussion that when the graphical technique is used, many researchers feel N FRVs calculated are in excess of the actual amount of $\mathrm{N}$ fertilizer replaced. This may be true when these estimates are made in relatively short-term experiments, especially with lots of year-toyear variation, but in experiments such as those reported here, the systems have been conducted over a number of years encompassing many different growing season conditions (considerable temporal variation), and the amount of $\mathrm{N}$ supplied to the following crops has been relatively consistent. Several attempts to correlate some of the year-to-year variation in the amount of $\mathrm{N}$ fertilizer replaced with previous crop (soybean) yield levels, previous year precipitation, and in-season precipitation resulted in no improvement in our estimate. Over the

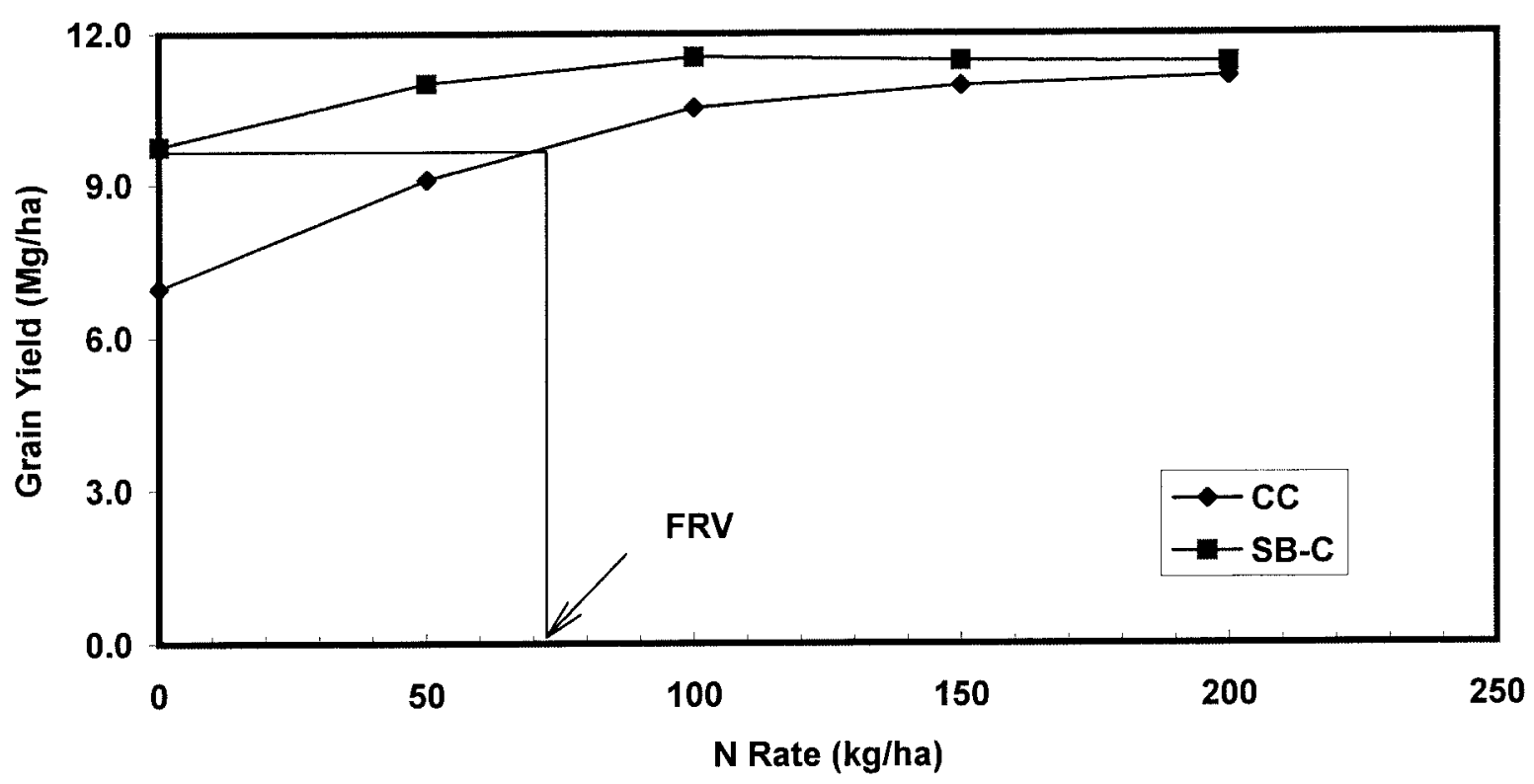

Fig. 3. Average corn grain yield response to $\mathbf{N}$ fertilizer applications in continuous corn (CC) and soybean-corn (SB-C) irrigated cropping systems at Shelton, NE (1993-2002). FRV, fertilizer replacement value. 
duration of both the rainfed and irrigated experiments, the fertilizer $\mathrm{N}$ replacement values estimated have been consistent and real.

Blevins et al. (1990) also reported that N FRVs estimated using this technique differed depending on what nonlegume grain crop followed the legume. Our results are similar to those of Blevins et al. (1990) in that we also obtained a different N FRV at Mead when our nonlegume grain crop following soybean was corn vs. sorghum, except that our values did not differ as greatly between the crops. In our estimate, the increase in the amount of $\mathrm{N}$ supplied to sorghum compared with corn by the N FRV technique should be expected. In all 20 yr of our study at Mead, sorghum has always matured a month or more later than corn in the fall, which gives it at least $30 \mathrm{~d}$ more to accumulate additional $\mathrm{N}$ mineralized from the soil in the soybean-sorghum system. This should not be a surprise because these crops differ in both their time of maximum growth and $\mathrm{N}$ uptake patterns.

These fertilizer $\mathrm{N}$ replacement values are especially significant when one considers the total amount of $\mathrm{N}$ fertilizer replaced over the duration of these studies. The total amount of $\mathrm{N}$ replaced for the $20 \mathrm{yr}$ at Mead was approximately 1300 and $1600 \mathrm{~kg} \mathrm{ha}^{-1}$ in the soybean-corn and soybean-sorghum cropping systems, respectively. At Shelton, the total amount of $\mathrm{N}$ replaced for the $10 \mathrm{yr}$ was approximately $650 \mathrm{~kg} \mathrm{ha}^{-1}$ in the soybean-corn cropping system.

Current fertilizer $\mathrm{N}$ recommendations in this area of the Corn Belt are based on late-fall or early-spring soil tests, neither of which has been able to detect or reflect this soybean $\mathrm{N}$ credit. The difference in $\mathrm{N}$ credit that we obtained for our corn and sorghum crops indicated this $\mathrm{N}$ does not become available till much later in the growing season and makes it difficult to detect with soiltesting methods. Our results, obtained from two longterm experiments conducted over a wide range of weather conditions under both rainfed and irrigated conditions, indicated a soybean $\mathrm{N}$ credit of approximately 65 or $80 \mathrm{~kg} \mathrm{~N} \mathrm{ha}^{-1}$ for a following corn or sorghum crop, respectively. This amount of additional $\mathrm{N}$ available to the following crops in 2-yr cropping systems including soybean must be considered when $\mathrm{N}$ fertilizer recommendations are formulated. Failure of farmers to factor this additional $\mathrm{N}$ into fertilizer $\mathrm{N}$ recommendations for the following crop results in excessive applications, increasing the amount of $\mathrm{N}$ available for loss from the system, either by leaching or denitrification. Nitrogen fertilizer applications in excess of crop need results in increased expenditures for unnecessary inputs. Nitrogen crediting also provides an additional justification for the use of crop rotation systems, which increase crop diversity and provide farmers with better workload distribution.

\section{REFERENCES}

Baldock, J.O., R.L. Higgs, W.H. Paulson, J.A. Jacobs, and W.D. Shrader. 1981. Legume and mineral N effects on crop yields in several crop sequences in the upper Mississippi valley. Agron. J. 73:885-890.

Baldock, J.O., and R.B. Musgrave. 1979. Manure and mineral fertilizer effects on crop yields in continuous and rotational crop sequences in central New York. Agron. J. 72:511-518.

Blevins, R.L., J.H. Herbek, and W.W. Frye. 1990. Legume cover crops as a nitrogen source for no-till corn and grain sorghum. Agron. J. 82:769-772.

Bullock, D.G. 1992. Crop rotation. Crit. Rev. Plant Sci. 11(4):309-326.

Bundy, L.G., T.W. Andraski, and R.P. Wolkowski. 1993. Nitrogen credits in soybean-corn crop sequences on three soils. Agron. J. 85:1061-1067.

Ding, W., D.J. Hume, T.J. Vyn, and E.G. Beauchamp. 1998. Nitrogen credit of soybean to a following corn crop in central Ontario. Can. J. Plant Sci. 78:29-34.

Harris, G.H., and O.B. Hesterman. 1990. Quantifying the nitrogen contribution from alfalfa to soil and two succeeding crops using nitrogen-15. Agron. J. 82:129-134.

Hesterman, O.B., M.P. Russelle, C.C. Sheaffer, and G.H. Heichel. 1987. Nitrogen utilization from fertilizer and legume residues in legume-corn rotations. Agron. J. 79:726-731.

Ladd, J.N. 1981. The use of ${ }^{15} \mathrm{~N}$ in following organic matter turnover, with specific reference to rotation systems. Plant Soil 58:401-411.

LaRue, T.A., and T.G. Patterson. 1981. How much nitrogen do legumes fix? Adv. Agron. 34:15-38.

Peterson, T.A., and G.E. Varvel. 1989a. Crop yield as affected by crop rotation and N rate: I. Soybean. Agron. J. 81:727-731.

Peterson, T.A., and G.E. Varvel. 1989b. Crop yield as affected by crop rotation and N rate: II. Sorghum. Agron. J. 81:731-734.

Peterson, T.A., and G.E. Varvel. 1989c. Crop yield as affected by crop rotation and N rate: III. Corn. Agron. J. 81:735-738.

Russelle, M.P., O.B. Hesterman, C.C. Sheaffer, and G.H. Heichel. 1987. Estimating nitrogen and rotation effects in legume-corn rotations. p. 41-42. In J.F. Power (ed.) The role of legumes in conservation tillage systems. Soil Conserv. Soc. of Am., Ankeny, IA.

SAS Institute. 1992. SAS/STAT user's guide. 4th ed. SAS Inst., Cary, NC. 